\title{
A burning issue? Governance and anti-incinerator campaigns in Ireland, North and South
}

\author{
Liam Leonard ${ }^{\mathrm{a}}$, Peter Doran ${ }^{\mathrm{b}}$ and Honor Fagan ${ }^{\mathrm{c}}$ \\ ${ }^{a}$ School of Business \& Humanities, Institute of Technology, Sligo, Ireland; ${ }^{b}$ School of \\ Politics, Queens University, Belfast, Northern Ireland; ${ }^{c}$ Department of Sociology, \\ National University of Ireland, Magnooth, Ireland
}

The decades of conflict in Northern Ireland created divisions between communities, with few opportunities for cooperation. However, in the 1990s opposition to a proposed cross-border incinerator brought the divided communities together. The 1990s economic boom in the Republic of Ireland generated a waste management crisis as the by-products of rampant consumerism overwhelmed the state's rudimentary waste disposal system. Three Irish anti-incinerator campaigns which have pitted local communities against the Irish state or the Northern Ireland Department of the Environment are examined. Community attempts to gain leverage within the political governance frameworks in operation on both sides of the border are examined and the various ways in which environmental movements respond to the crisis of waste management under different governance regimes are illuminated.

Keywords: community; mobilisation; governance; opportunities; movements

\section{Introduction}

Anti-incineration campaigns emerged on the island of Ireland during a particular phase of economic growth with increased consumption in the Republic alongside conflict resolution in the North from the late 1980s through to the turn of century. The political frameworks that existed on both sides of the border whilst these changes occurred are based on partnership agreements between national and regional political entities or the local authorities and the corporate sector. This wider political opportunity structure included the European Commission (EC), and in the Northern jurisdiction, the UK government, the Northern Ireland Office and the Department of Environment

*Corresponding author. Email: liam_leonard@yahoo.com 
(DoE), as well as the post-1998 devolved Stormont Assembly and, in the south, the government in Dublin and the waste management industry. Those opposed to incineration technologies included a loose coalition of citizens with concerns about health risks, environmentalists and, in the Northern case, both nationalists and unionists who had historically been trenchant opponents on almost every other local issue. ${ }^{1}$ We will argue that the partnership arrangements that existed in both jurisdictions, but to different extents, from the outset excluded communities that opposed incineration from the core of political decision-making. Their campaigns achieved various degrees of political access with differing consequences. We examine the dynamics and features of three campaigns against incineration in the two political jurisdictions in their governance context.

Following Rootes we note that community-based environmental movements ebb and flow within local frameworks:

local environmental campaigns are ubiquitous and recurrent, even in times when environmental issues are not salient on national agendas ... Local environmental campaigners are variously related to national and local organisations, and the peculiarities of place are one factor in that variation. But place itself acquires meaning through campaigns, and communities forge identity even as they mobilise against threats to their survival. (Rootes 2007, p. 722)

Our focus here is on local environmental movement activism in the context of waste infrastructure and its political governance. We will examine the movement dynamics of three regional campaigns that occurred in the 1990s and early 2000s in Derry, Galway and Cork regions. A waste management crisis emerged as a result of increased consumption rates as economic growth was achieved in the Republic and as a post-conflict process was emerging in the North. European directives led to a shift from a traditional (over-)reliance on landfill, with regional waste management plans including incineration as an option for the first time. We also outline a series of dynamics in the mobilisation of networks for the anti-incinerator and zero waste movements, the role of experts and advocates with international experience of similar campaigns, the significance of cultural capital in the mobilisation process, and the differences in rural and urban campaigns. Finally we examine the extent to which political access was achieved by community groups originally alienated from the diverse systems of political partnerships in both jurisdictions.

\section{Governing waste}

Waste management issues and the broader issue of sustainable development are, ultimately, issues concerning governance in contemporary societies. Governance is taken to refer to the sum of interactions between civil society and governments. Good governance is currently taken to include transparency, effectiveness, openness, responsiveness and accountability. These are all criteria by which we can legitimately evaluate the government of the day in respect of its dealing with civil society and its concerns. So, if sectors of civil society - 
concerned individuals, community groups and environmental groups - have concerns about the government's waste management strategy (whether as discrete projects or as an indicator of the broader concern with sustainable development in particular), we can expect them to be dealt with according to the internationally accepted criteria of good governance.

The essence of governance is its focus on mechanisms to govern society which do not rest on the use of authority or of sanctions by government. Forms of partnership with the organisations of civil society are one of the preferred options of the governance approach. Following one of the authorities in this area, 'governance recognises the blurring of boundaries and responsibilities for tackling social and economic issues' (Stoker 1998, p. 21). Both in terms of strategic decision-making and of service delivery there is now a growing critique of the 'Westminster model' (see Bache and Flinders 2005, Bevir 2008) on the grounds that its centralised powers lack flexibility and the necessary counterbalances. Government by central decree is becoming increasingly unpopular in contemporary western society, and is often replaced by a more consensual model based on multi-agency partnerships or some hybrid model. The notion of governance (and particularly multi-level governance in an EU context) responds to these perceived weaknesses with an ideal type stressing the complexity of modern-day political management and the need for ongoing citizen participation in that process.

When we look at the production and management of waste it is useful to think in terms of multi-scalar processes, where rescaling of waste production in the era of glocalisation has occurred and where its successful management relies on governance at multiple levels - global, regional, national and local. EU directives on waste have been the key driver of waste management policy in Ireland (Fagan et al. 2001). The European Economic Community (EEC) Act of 1972 gave direct precedence to European acts over domestic laws and constitutional provisions in the Republic and in Northern Ireland. The ratification of the Single European Act (1986), the Treaty of Maastricht (1992) and the Treaty of Amsterdam (1997) further ensured the supremacy of EU law over domestic law. In its programme for dealing with waste the EU produced legislation, which includes Directives on dangerous substances, waste oils, groundwater, urban waste water, licensing regulations, the disposal of $\mathrm{PCB} / \mathrm{PCT}$, toxic waste, sewage sludge in agriculture, emissions from waste incineration plants, the disposal of animal waste, and batteries containing dangerous fluids. It likewise set targets for reduction in all waste streams, and set very specific timeframes for national governments to meet these reductions. For example, for the Republic of Ireland's municipal waste stream, there is a national target of 35\% recycling by 2013 and a household waste diversion from landfill target of $50 \%$ by $2013 .^{2}$

\section{The state governance context}

With the EU able to enforce sanctions on the nation-state and the national government needing to radically change the direction and composition of waste 
flows, the drawing up and implementation of strategy quickly became an issue of governance at a national level. Government by central decree on the waste management issue was not an option since the government had moved to a governance model patterned on consensual politics and multi-agency partnerships. From this perspective, self-governing networks in relation to waste management were very much favoured by the state. The capacity to 'get things done' did not simply rest on the power of government to command, and commands would only be invoked in the last instance. In order to reach the targets it was considered necessary to bring key players such as "private enterprise' into some form of partnership. In 2001 in the South there was a need for an estimated investment of $€ 1$ billion over a 3-5 year period to implement the waste development plan (Forfás 2001, p. vi) and the National Development Plan envisaged this coming mainly from the private sector.

Clearly, Ireland faced a gruelling task to organise a strategy to divert waste away from landfill, to reach targets set at a five-fold increase in recycling and to find the finance for the infrastructure, especially if the objective was for the private sector to answer this call. Private capital was thus seen a necessary 'node' in the governance of waste management (Fagan 2004). Offe's (1987) argument that the neo-corporatist system focuses on 'technocratic criteria' is illustrated by the policies generated under these 'crisis' conditions. In such conditions, the government's gaze focused on the private sector and on the waste industry's multinational giants, leaving sustainability concerns secondary to costs and slow, deliberatively reached democratic solutions secondary to immediate technocratic solutions. Waste governance in Ireland, from this perspective, could not be resolved at its most radical level - that of sustainability. The plans relied heavily on the treatment of waste through 'thermal treatment plants' and on recycling to be funded primarily by private enterprise. In short the partnership arrangements involved a hierarchisation of partners, with the role of the community or civil society partners being to consent to the technocratic logic of 'getting things done'. Partners offering solutions to the crisis and engaging in problem solving were 'more equal' in the partnership than those who could be labelled 'oppositionists'. Clearly the way governance is implemented is part of this political process and should not be seen as a deus ex machina. Being oppositionist brings with it a danger of exclusion from partnership arrangements. Murray (2006) argues that such multi-level partnership arrangements involving state and corporate entities may serve to further isolate working class communities and also marginalise them from the local community perspective. It is perfectly rational that in a 'problem-solving partnership', 'partners' offering solutions to the crisis and engaging in problem solving would be 'more equal' in the partnership than those labelled 'oppositionists' and risking exclusion from the prevailing partnership arrangement (Gaynor 2008).

While governance necessitated consultation and the introduction of key players into the process, the unequal balance of power in the consultations and the fact that some partners were 'more equal than others' resulted in outright 
contestation of the plans in the South, where plans were about a year in advance of those in the North. How did communities and activists contest their respective government's preferred waste management strategies? Discursively they contested the strategy as 'bad' governance which they located in what they termed a 'non-consultative' process. The environmentalists and local communities threatened by incineration plans were deeply critical of what they perceived as the 'façade' of consultation that had been put in place (Fagan et al. 2001, p. 18). There was a widespread perception at community level that government 'consultations' (often dictated by EU regulations) on the development of incinerators were simply empty rhetorical exercises for communities to 'let off steam' but were not designed to change decisions already taken on technical grounds (Fagan et al. 2001, p. 19).

In the North, the proposed all-Ireland incineration plant for toxic waste was blocked by cross-border and cross-community opposition. In the South the opposition to the location of incineration plants began, fuelled by anger about the nature of the consultation process that had produced the plans, and drove the waste management strategy into political crisis in 2000-2001 as local communities blocked the sub-regional plans. In the North, the failure of the proposed DuPont plans for an all-Ireland toxic waste incineration plant drove cross-border cooperation into the background. A second development that minimised cross-border cooperation was, curiously, the impact of the political backlash to the waste management plans in the South. Alongside the opposition to the DuPont plant, that opposition to plans for large incinerators in the South created a situation where the Northern planners watched with horror as they saw the backlash against plans for large-scale incineration plants unfold. Not wishing to go down the same road, waste authorities in the North proposed many small incinerators instead and community buy-in was considered to be a priority. Given, therefore, that there appeared to be no urgent reason for anything but small-scale regional planning, cross-border cooperation went on the backburner and no one seemed to be actually working on developing an all-island strategy.

The Southern state moved into action against the blocking of the plans by anti-incinerator activism. The first Environment Minister to deal with the issue, Noel Dempsey, removed local councillors (who had been subject to public will) from the decision-making process, and replaced them with the county manager, a government employee. So, in response to challenge from 'below', a central decree (government as opposed to governance) was used to achieve the localising or embedding of waste management. This is not to say that the Irish state entirely moved back to traditional government or rejected the principle of consensus politics and failed to involve itself in multi-agency partnership, but, rather, that it removed the locality from involvement in the decision-making process. The next Environment Minister, Martin Cullen, stated quite openly that the planning process on waste management was 'over-democratised' and that he did not believe it was 'adding anything to it by having so many layers involved' (Irish Times, 12 August 2002, p. 1). 
The so-called 'fast-tracking' for waste management plans had to be implemented, and An Board Pleánala (the Planning Board) became a 'onestop shop' for assessing all plans for new waste management facilities. The Minister, rather contradictorily, insisted that he was not removing the rights of any groups or individual to express their views - 'That is sacrosanct, but I don't see a need for these views to be expressed at so many different levels' (Irish Times, 12 August 2002, p. 1). In other words, repetition of oppositional views at multiple levels in a multi-layered process of governance was a source of irritation for government.

This suggests a particular multi-faceted and shifting dynamic of actors in the governance process, with some gaining power and others losing it in a complex political process of action and reaction. The discourse of governance certainly did not ensure that the political will of communities would prevail. That local communities were important players in the dynamic is without question, but there were ebbs and flows in their political power. Let us look in more detail at these in the three case studies that follow. In terms of governance, the EU is a key player in that it regulates waste and sets the scene for its regulation at national level. However, EU policy emerges from a network of actors and competing agendas and is translated into national policy through a similar network. While we can clearly see the European agenda informed by concerns with environmental sustainability, we can equally see the market-driven notions of development being played out when it comes to its implementation at national level. At the implementation stage the contradiction between the concepts of economic development (market-driven in its capitalist form) and sustainability (the earth as limited resource) play themselves out, with the former being presented as more urgent than the latter.

\section{Ireland: the North-South governance context}

Prior to the Belfast Agreement which brought an end to the conflict in Northern Ireland, cross-border cooperation had existed, as we will see in the case of the DuPont proposal to site an all-Ireland toxic waste incinerator in Northern Ireland. The DuPont campaign took place at a critical period in waste management politics, North and South. Fagan et al. (2001) noted that in both parts of Ireland waste management was entering a critical moment in light of new EU regulations and the attitude of many local communities to incineration in particular. European Directives that required governance consistent with enhanced environmental sustainability were affecting industry, commerce, local authorities and households in an increasingly direct way. After intensive negotiations between the Irish and British governments (and the various political parties), the specific nature and administrative form of NorthSouth cooperation was put in place in December 1998. Six North-South implementation bodies were established, covering waterways, food safety, trade and business, EU programmes, the Irish language and agriculture/marine matters. Also, the so-called Trimble-Mallon statement in December 1998 
contained an initial list of six matters for North-South cooperation through existing North-South public policy bodies. These were to include transport, agriculture, education, health, tourism and the environment, the latter specified to include research into environmental protection, water quality and waste management. So waste management in Ireland became part of an all-island public policy framework. But we can also note that the Du Pont case prepolitical settlement had already refigured this outcome as waste management was already being seen as an issue transcending political borders in a small island.

Policy-makers on both sides of the border were facing the introduction of significant targets, including a considerable reduction in the amount of waste going to landfill, and increased energy recovery from waste. In 1988, the Department of the Environment in the South commissioned consultants to prepare a feasibility study on a 'national' toxic waste incinerator. By 1990, consultants on both sides of the border had advised their respective governments of the desirability of an all-island solution to the challenge of disposing of toxic waste. Key to considerations on both sides of the border were developments at the European level. The ratification of the Single European Act (1986), the Treaty of Maastricht (1992) and the EC Waste Strategy launched in 1989, enshrining the principle of sustainable development, combined to force governments in Dublin and Belfast to make waste management a domestic priority. The principle of 'self sufficiency' in dealing with waste disposal was established in European legislation in 1991 and economies of scale pointed to the need to cooperate. As a Northern Irish civil servant put it succinctly in 2001 'the whole North/South thing is where [waste management] is going to happen', and according to him two things were fundamental: 'one is scale and the other one is working together' (Fagan et al. 2001, p. 44).

\section{Case study I: DuPont, Derry (Northern Ireland)}

In one of the island's most celebrated campaigns against a proposed toxic waste incinerator, communities in Derry and Inishowen took on Derry's biggest and most important employer, DuPont, at Maydown on the outskirts of the city. During the 18-month campaign (1990-1991) a question of environmental justice merged with the dominant concerns of citizens and communities emerging from a deep political conflict and history of communal division. Derry - sometimes regarded as the crucible of the civil conflict and nationalist/ Republican assertion of their civil and political rights - provided the mise en scene for a successful campaign, which would tap into a number of discourses drawing from a distinctive political culture and set of historical circumstances. Not least of these was the ease with which Protestant and Catholic, Unionist and Nationalist, citizens and politicians contradicted the dominant narrative of division and conflict to make common cause in their assertion of the city's and region's right to say 'no' to what was widely regarded as an imposition 
cooked up by outsiders, including corporate actors at DuPont and government ministers in both Dublin and Belfast. This case study provides valuable material for an understanding of how divided communities might mobilise around environmental issues and the way new environmental discourses are constructed on pre-existing community consciousness. The name of the DuPont company was already known on both sides of the border when the Derry campaign was launched. In 1974, the company had given consideration to the establishment of a plant at Cork Harbour to extract titanium dioxide from limonite ore from Australia. Controversially, the company had proposed to dump the resulting waste in the open sea. Sixteen years later, the antiincinerator campaign took place at a critical period in waste management politics, North and South.

The origins of the proposal for an all-island incinerator were recommendations set out in a feasibility study commissioned by the Republic's Department of the Environment. In turn, consultants commissioned by the Department of the Environment in Northern Ireland recommended that the Department engage with its counterpart in Dublin. This was the background to a visit by Flynn to the DuPont plant in 1990. The company engaged the Irish Government with a view to importing 14,000 tonnes of the proposed incinerator's projected 20,000 tonnes annual capacity for treatment at its Derry facility. The company ruled out 'importing' waste from Britain to the largely nationalist city of Derry. Allen (1992) concluded that the consultants' suggestion that there should be a cross-border solution to the toxic waste challenge which had bedevilled successive Dublin governments seemed to offer a way out for the Irish state.

Reviews of waste strategy on both sides of the border had coincided with DuPont's plans to upgrade its incineration capacity at the Derry plant. Economic considerations for the industry, including the prospect of grant aid to DuPont, merged with the logics of the European Commission's first broadbased communication on waste, A Community Strategy for Waste Management (1989), including the 'proximity principle'. The consultants advising the Department of the Environment in Northern Ireland, Aspinwall and Co. Ltd, for example, noted that the waste markets on the island could not support incinerators in both Northern Ireland and the Republic, unless operators were to consider importing wastes from other countries. The consultants noted that proposals for a single viable incinerator servicing the waste markets in both jurisdictions would fall within the spirit of the 1989 Waste Strategy, especially since DuPont had each year been exporting 700 tonnes of hazardous waste to Finland and France for incineration.

Activists from Derry and Donegal reacted with shock when they learned of the proposals to site an all-island incinerator at the DuPont plant, five miles outside Derry, in early 1991. Local political representatives were also quick to respond to the announcement and an emergency meeting of Derry City Council's Environmental Protection Committee convened. The Social Democratic and Labour Party (SDLP) group, which controlled the Council at the 
time, relayed the 'alarm and concern' among local politicians. While consensus emerged amongst Nationalist and Unionist politicians, their opposition was based on a variety of arguments. Some Unionist politicians, reflecting the deep resentment stirred by the Anglo-Irish Agreement, opposed Dublin's interference. Sinn Fein representatives, with close ties to grassroots communitybased organisations, were quick to articulate technical, economic and social arguments against incineration. The grassroots campaign, for the most part, maintained a firewall between cross-community and cross-border activism and the role of local politicians, and elected representatives from political parties were not encouraged to address public rallies.

DuPont's proposal was to take toxic waste from across the island to ensure the technical and financial viability of the new plant. The imported element would come from chemical and pharmaceutical companies based in Dublin and Cork. Du Pont launched Northern Ireland's biggest ever industry-sponsored public information campaigns to explain its plans and offer reassurance to the local population. The Derry population was not known for its interest in environmental issues (Allen 1992, p. 3). Key drivers of the initial campaign formation were prominent activists based in Donegal, just across the border, in the Republic of Ireland. A feature of the cross-border campaign was the distinctive mobilising narratives deployed on each side of the border. While established community-based environmental lobby groups in Inishowen, Donegal, focused on the perceived pollution threat, the debate in Derry focused as much on issues of the rights of the community to participate in decision-making, failures in environmental governance, and the economy. The Derry-based campaign thus resonated with that city's historical identification with public protest in pursuit of civil and economic rights.

The cross-border campaign was launched at a meeting in Derry in January 1991. Within 24 hours, at a meeting of Derry City Council's Environmental Protection Committee, opposition to the incinerator proposal was made clear. A campaign 'Briefing Paper' (1991) drawn up by the Derry Development Education Centre set out a number of influences on the campaign and key arguments that place the events in context, on the eve of the UN Conference on Environment and Development. The major considerations for campaigners included: the 1972 London Convention to outlaw the dumping of waste and incineration in the North Sea; a local history of industrial toxic waste disposal on farmland; a perception that accommodating industry's preference for incineration could reduce pressure to address waste prevention; the risk of large amounts of toxic waste being transported to Derry and the risks associated with Derry becoming a magnet for all future toxic waste generated on the island; the scientific uncertainties surrounding the 'cause-effect' relationship between industrial pollution and public health; a perception that pollution monitoring had been 'piecemeal'; and a failure to enforce emissions regulations and punish those in breach of regulations.

Having noted that the proposed site for the incinerator was closer to villages in the Republic of Ireland than to the city of Derry, campaigners 
discussed their suspicions about atmospheric pollution drifting across Lough Foyle from Derry to Donegal. The Inishowen Environmental Group in Donegal tapped into these suspicions to mobilise public support for the antiincinerator campaign, claiming that marine and air pollution from industrial activity in Derry had already resulted on both sides of Lough Foyle.

The focus for the mobilisation of groups in Derry and its environs was a development education centre, with trade union ties and funding. The Derry Development Education Centre (DDEC) played a key role in providing a secretariat for a network of 63 local groups, many of them specifically set up in neighbourhoods for the purpose of opposition across the city and on both sides of the border. The Centre exploited links with the trade union movement, international development and environment NGOs, and industrial health and safety networks. The DDEC worked alongside veteran community development organisers, some with a history of campaigning and mobilisation stretching back to the early civil rights movement in the city in the late 1960s. Conventional campaign tactics were deployed, including public rallies, a media strategy, lobbying, theatre and fund raising.

The campaign counted support from local bishops, elected representatives, the media, farmers' groups, including the Ulster Farmers Union, community groups, doctors, trade unions and women's groups. They drew on advice from a number of professionals within their ranks, including energy consultants, engineers, marine biologists, farming experts, architects and health workers. The campaign also had significant access to research and expertise from across Ireland, the United Kingdom and the United States. Greenpeace advisors offered support on the media strategy and tactics.

\section{Timeline for the Northern campaign}

November 1988: Then Republic of Ireland Environment Minister, Padraig Flynn, commits to incineration as a long-term solution to the chemical industry's waste problem, speaking at a conference in Cork. He commissions consultants, Byrne O'Cleirigh, to prepare a feasibility study on a 'national' toxic waste incinerator.

February 1989: Report by the consultants, Byrne O Cleirigh, commissioned by Flynn. Tenders for a national incineration project invited in the Republic of Ireland.

June 1990: Consultants Aspinwall and Co. Ltd present findings on the future of waste disposal in Northern Ireland, in a report commissioned by DoE NI. They include a recommendation that NI Ministers undertake joint discussions with their counterparts in the Republic of Ireland. The talks would determine the feasibility of including Northern Ireland in the Republic of Ireland's proposals for high temperature incineration. The consultants' report cited the EC Waste Strategy (1989).

December 1990: With no decisions taken on tenders for the Republic of Ireland facility, Flynn visits Du Pont in Derry, to pursue possible cooperative arrangements involving the administrations in Belfast and Dublin. 
5 December 1990: Du Pont submits application for planning permission to replace a solid waste burner to burn lycra waste. (Du Pont never submitted a request for permission to develop the proposed all-island facility.)

18 January 1991: The Inishowen Environmental Group in Donegal poses key questions about DuPont proposals in an article published in the Derry Journal newspaper.

21 January 1991: 120 people attend an anti-incineration briefing and launch of campaign in Derry's Central Library.

21 January 1991: Greenpeace/Cork Environmental Alliance meets Derry City Council officials. At least one solidarity rally was staged in Cork to coincide with a protest convened in Derry during the 1991 campaign.

30 January 1991: Formation of Campsie Residents against Toxic Emissions, involving residents living in the environs around the Du Pont plant.

31 January 1991: The Economy Minister for Northern Ireland, Richard Needham MP and the Environment Minister for the Republic of Ireland, Padraig Flynn, meet at an Anglo-Irish conference in Dublin and discuss the proposal for an allisland facility at DuPont.

16 March 1991: First anti-incineration rally in Derry.

20 August 1991: Du Pont announces that it is to begin an environmental impact study (EIS) in preparation for a planning application for an all-island toxic waste incinerator.

December 1991: DuPont announces that it is abandoning plans to build an allisland incinerator at its Maydown plant in Derry. The decision, which had been taken out of the hands of the Derry plant operators, is attributed to strategic financial considerations.

Ultimately, DuPont announced in December 1991 that it was abandoning the incinerator plan. Underlining the importance of local autonomy and democratic decision-making as a feature of the campaign, the company attempted to signal that the final corporate decision had been taken at an international level 'so that both the responsibility for and the cause of deciding not to proceed appeared to be taken out of the local arena' (Jordan and Gilbert 1999, p. 2).

An editorial published in the main local newspaper, The Derry Journal (3 May 1991), had come out in strong support of the anti-incineration campaign and neatly located the campaign's arguments within the historical and political context of the city. The editorial stated that there were good reasons for the opposition given that the city had suffered enough from discrimination from Stormont governments over two generations. Local people, it continued, were in no mood to allow the installation of a plant they believed would damage its environmental attractiveness and stunt hopes for an economic revival. The editorial concluded with a warning to both the Northern Ireland Office and the Dublin Government: 'The dismissal of community protests from Derry played a major part in precipitating the civil rights movement in the North. The toxic incinerator has become the biggest 
issue to command support across political divides since those times. Both the Northern Ireland Office and Dublin should tread warily.'

\section{Frames and meanings}

Jordan and Gilbert (1999) have studied the 'competing discourses' or 'distinctive social meanings communicated through the use of language' which were at work during the Derry incinerator dispute. They concluded that while both supporters and objectors shared the language and discourse of 'environmental management', only the objectors mobilised around 'environmental representation' and this imbalance contributed significantly to the defeat of the proposed incinerator. As Jordan and Gilbert (1999) noted, unlike expert discourse, the discourse of 'environmental representation' does not rely upon a strict bifurcation of 'environment' and 'community'. The objectors successfully established legitimate claims by drawing on this discourse, rhetorically tying a particular social grouping or community to a particular physical space and environment (Jordan and Gilbert 1999, p. 5), as captured in one quotation recorded in the Derry Journal (27 September 1991):

Too often the word 'environment' is used in a narrow and restricted sense as almost exclusively confined to the physical surroundings ... If the environment includes all aspects of surroundings then the cultural and social dimension is just as important as the physical and the geographical and must be included in any environmental impact assessment.

Emerging from conflict, and anticipating a 'peace building' era of new choices about infrastructure, the economy and the nature of local development, the DuPont campaign forced open debates that other parts of the island had already rehearsed. Environmental and health considerations were framed by a strong sense of local community. For historical reasons, activist communities in both Derry and Inishowen were wary of remote government decision-making and a perceived neglect in terms of economic and development outcomes. This gave a very local and context-specific flavour to arguments around access to information and participation in environmental decision-making. The political environment created by the highly contested Anglo-Irish Agreement deepened suspicion on the Unionist side, while on the nationalist side promises of job creation came to be seen as an attempt by the authorities to exploit Derry's status as an unemployment blackspot rather than a bona fide attempt to redress an historic injustice.

Jordan and Gilbert (1999, p. 10) suggest that the Derry dispute was essentially a political debate concerning human relations. Protagonists used ostensibly 'environmental' concepts to frame arguments concerning appropriate social relations, in this case about decision-making over local development. One letter writer to the Derry Journal (22 January 1991) was quite explicit in challenging the paper's editorial writer to accept that a 'community values' perspective was just as valid as that of scientific expertise, which must be assessed given that 'the history of science and technology, or rather the 
history of the use of science and technology reveals an absence of objectivity and very strong value loading'.

\section{Case study II: Galway for a Safe Environment (Republic of Ireland)}

The regional waste plans for the Republic of Ireland included three options: landfill (which was the destination for over $90 \%$ of the country's waste), recycling and incineration. The inclusion of plans for an incinerator at certain named locations in and around the western city of Galway caused local professionals to instigate a campaign of opposition to the siting of the plant, while their campaign would emerge into a wider anti-incineration campaign with extended links regionally and globally, while attempting to influence the 2002 General Election (Leonard 2005). The local campaign of Galway for a Safe Environment (GSE) opened up three main frames: highlighting health risks; embracing wider politics and going 'beyond NIMBY'; highlighting democratic deficit.

These three frames were not distinct, and tended to overlap as GSE's leadership attempted to politicise their campaign by moving 'beyond NIMBY' (Szasz 1994). The initial phase of the campaign gave rise to a series of protests, marches and media appearances that allowed GSE to highlight the issue of health risks posed by incinerator emissions. GSE's health frame provided many potent images for the anti-incineration activists to manipulate in order to create issue salience amongst the public. All aspects of community politics were integrated into GSE's anti-incinerator repertoire, including exploiting antiabortion sentiment still prevalent in the wake of two referendums on that contentious issue. (GSE promoted the image of dioxins in baby's milk as one of the main health risk concerns.) Furthermore, GSE outlined the damage caused to processes when pastures and farms were exposed to toxins including furans and dioxins in emissions from incinerators. This was done in order to exploit another cultural frame based on existing concerns about toxic pollution from multinationals in rural areas.

In so doing, GSE was able to extend the cultural frame to embrace rural environmental sentiment, while also preventing a rural/urban divide, something that would have benefited its opponents (Leonard 2008b). This strategy emerged from the prior experience of some GSE committee members, who had knowledge of anti-incinerator campaigns in Canada. These links to international anti-toxics campaigners such as Professor Paul Connett of St. Laurence University, New York, would provide GSE with a vast resource of scientific data that provided the basis of their health frame. In fact, GSE were able to provide a great deal of information on incineration to the public, local politicians and media sources, to the extent that the interest-driven data came to shape the debate, with the state and industry being forced into a reactive stance. The forms of action taken by the Galway campaign included a mix of street protests outside of City Hall, with spokespersons addressing alternatives such as the recycling based 'Zero-Waste' approach to waste at special meetings 
of the local authority. In this way, the Galway campaigners were able to maintain pressure on the local political structure, while providing a level of expertise to the local (and national) debate through their wider networks. At the height of its campaign, GSE was holding major public meetings debating the issue live on the evening news while its petition against incineration received 22,000 signatures in a city of 70,000.

This mobilisation of support was also reflected in the extent to which GSE influenced local councillors, who went on to reject the regional waste plan. Many councillors publicly stated that GSE's campaign had influenced their decision, while many reported an upsurge in voter concern on the issue. The state's response to this rejection of its waste policy was to rescind the decisionmaking powers of all regional councils on waste management issues, a move that provided GSE with the political opportunity of extending the democratic deficit frame. For GSE and its supporters, the state's initial approach to pushing through incineration without consultation or referring to any potential health risks in the regional plan was one example of a lack of accountability on transparency on the issue. However, the removal of the councillors' decisionmaking powers allowed GSE to re-frame the campaign by attempting to gain wider access to the political structures on a national level. The key opportunity for that strategy presented itself through the 2002 General Election. As the balance of political opportunities (another significant aspect in determining campaign outcomes) surrounding the anti-incinerator campaign continued to shift, GSE was able to extend the democratic deficit frame, gaining further leverage during the general election campaign. Having decided against running its own candidate in order to facilitate supportive political figures from the mainstream, GSE began to merge its three main frames into an offensive against Fianna Fáil, the main party of government. Moreover, while Fianna Fáil had targeted three seats in Galway West, GSE created strategic alliances with one government party (Progressive Democrat - PD) candidate and one opposition party (Greens) candidate to increase the chances of having a supporter in government (Leonard 2005). Ultimately, the return of the Fianna Fáil/PD coalition to power dealt a major blow to GSE's attempt to politicise its campaign. Essentially, GSE's key political alliances had proved to be no more than a 'perceived' opportunity (Tarrow 1998), rather than the key leverage that would lead to the campaign influencing policy at a national level. Nonetheless, while municipal incinerators for Cork and Meath (near Dublin) were announced in November 2005, any such plans for Galway had been shelved, with Fianna Fáil keeping one eye on the potential for populist backlash in future elections.

\section{Case study III: Cork Harbour for a Safe Environment (Republic of Ireland)}

Another site in the Republic, Cork Harbour, was part of a series of municipal incinerators announced by the state as part of seven regional waste plans in Dublin, the South-East, Galway, Limerick, the Midlands and the North-East 
(Fagan 2003, p. 67). Communities in these areas campaigned against the proposed incinerators, using collective action frames to create understandings about the potential health risks posed by incineration. The Cork campaign had marked similarities with GSE's, as political opportunities were provided by the state's technocratic approach to including mass-burn incineration:

One can see that incineration is the contested terrain in this case, as not one government policy or regional plan mentions the word 'incineration.' The word used repeatedly and pointedly is 'thermal treatment plant.' As in all conflicts, the discourse itself marks the terrain and the use of the work 'incineration' as opposed to 'thermal treatment plants' marks the political division. (Fagan 2003, p. 78)

Moreover, the state's own attempt to frame the waste issue in a less than up-front manner provided the first political opportunity for community campaigners challenging the regional waste plans. In December 2001, Indaver, the Belgian incineration company involved in all of the regional plants, lodged a planning application for a 100,000 tonnes per annum incinerator for hazardous and non-hazardous industrial waste, as well as an incinerator of equal size for municipal waste, at a site at Cork Harbour. This incinerator was opposed by activists in the Cork Harbour/Ringaskiddy area, which had been the site of previous disputes about toxic dumps and industries. This provided their campaign with further leverage due to the existence of many activists who had taken part in previous campaigns. As such, the resources of campaign and scientific expertise could be more easily mobilised. The proposed incinerator was opposed by local residents, who formed an alliance from the many existing environmental groups in the Cork area, under the name of the Cork Harbour Alliance for a Safe Environment (CHASE). The campaign gained momentum, and CHASE was able to claim to 'represent the views of 24,000 people' (Irish Examiner, 19 September 2003). CHASE followed similar strategies to Galway for a Safe Environment, by establishing a network of environmental groups, mounting a campaign of public protests and meetings. However, CHASE had one major difference in its strategic approach: it focused on a direct challenge to Indaver, rather than attempting to influence the political process. Indaver and the state were keen to site their incinerator at Ringaskiddy, Cork Harbour, as ' $60 \%$ of all hazardous waste in Ireland comes from Little Island and Ringaskiddy' (ibid.). Links were established between CHASE, GSE and the No Incinerator Alliance in rural County Meath, as resources and expertise were exchanged between the groups.

The CHASE campaign saw the appearance of many of the women and children in white boiler suits and oxygen masks, holding 'No to Incineration' placards, and presenting a striking visual profile (Irish Times, 17 January 2004). CHASE was able to frame the 'moral discourse' (Grove-White 1993, p. 20) surrounding the issue, depicting the children in a way which highlighted their potential exposure to the health risks of dioxins. The dispute was taken to a series of oral hearings, held at the Neptune Stadium in Cork. In this way, the campaign led by CHASE manifested itself in a manner that had become the 
norm for environmental disputes in Ireland. As legal challenges may only provide 'partial access' (Tarrow 1994, p. 86) but entail high costs, oppositional campaigners have less often had recourse to law than the EPA and the government. This is the reason such a strategy was avoided by Galway for a Safe Environment. Such strategic decisions provided GSE with a level of success, in contrast with CHASE. After a campaign lasting over two years, An Bord Pleanála (the Planning Commission) refused permission for the Ringaskiddy waste scheme on the grounds that the Environmental Impact Statement was inadequate, an incinerator for non-hazardous industrial waste was contrary to the Cork Waste Management Plan, would contravene materially the zoning of the site primarily for industry and enterprise, the scale, nature and purpose of the development would be fundamentally unsuitable to the site and 'that it would be close to high density housing'. These were amongst 14 points given for the refusal of planning permission at the site (The Irish Times, 17 January 2004).

The senior planning inspector's report ran to over 300 pages, and rejected Indaver's plan for an incinerator on the 14 counts. CHASE claimed a complete vindication of its position on the issue, as many of its objections formed part of the inspector's rejection of the incineration scheme. However, both the inspector and CHASE were soon to find that An Bord Pleanála would overrule the refusal and grant planning permission for Indaver's proposed plant, citing the prioritisation of government waste policy over all other considerations. An Bord Pleanála also had to consider the state's waste management framework, in which there is a preference for incineration over landfill. The board also considered the geographical location of a number of large-scale chemical and pharmaceutical industries operating in the Cork Harbour Area, and stated that Indaver's plant was 'an appropriate location for a necessary public utility' (Irish Times 17 January 2004). It also stated that such a plant would 'not injure the amenities of the area or be prejudicial to the future for port-related development' (ibid.). The then Green party representative for the Cork South Central constituency, Dan Boyle, said this decision was a 'political' one, and accused the board of 'caving in' to government pressure. He questioned the fairness of the planning process, adding that the campaign against the plant would continue: 'This battle now moves to its next stage, where many thousands who have campaigned against this incinerator will look for something in the planning, political and judicial process that can deliver them true justice' (ibid.).

However, the state's response to CHASE, which included the granting of a limited degree of access through the oral hearing, followed by the overriding of An Bord Pleanála Inspector's own findings, represented a reversal of fortunes for the CHASE campaign, and indicated the limitations of the oral hearing approach for public campaigns, something which has been noted about previous community campaigns in the Cork region (Peace 1997). The CHASE campaign demonstrated how creating 'increased access' (ibid.) and the ability to create 'alignments' with existing environmental activists in the Cork area, 
together with limited support from allies such as An Bord Pleanála's inspector, provided assistance. Nevertheless, 'the strength of state' (Tarrow 1994, 1998) was the decisive factor, as the state overruled the Board's inspector in the interest of pursuing its wider policy aims.

\section{Conclusion: growth, waste and peace in the new Ireland}

We have examined the mobilisation and constellations of political opportunities surrounding the governance of waste in both jurisdictions in Ireland. Each of the campaigns met with differing outcomes, due to the nature of the political frameworks in those jurisdictions. The three Irish case studies presented here demonstrate differing responses by social mobilisations to the state's governance of waste management. Despite what many consider to be the two political success stories of recent times in the two jurisdictions the 'peace process' and the establishment of a devolved, consocial Assembly in Northern Ireland, and the rise of the neo-corporatist 'social partnership' arrangements which underpinned the 'Celtic Tiger' economy in the Republic local communities have suffered severe fears about the risks of incineration and are unable to have their concerns dealt with without resorting to social mobilisation. While the major political agreements represent a considerable achievement, they have created a degree of exclusion for those groups that remain outside the socio-economic and political elites that have emerged in Belfast and Dublin in the last two decades.

Davies (2007) and Garavan (2007) have examined the impact of environmentally orientated community movements in Ireland. Despite having local political access and expertise, community campaigns have been excluded from the political core in both jurisdictions due to the influence of neo-corporate partnerships that prioritised growth over community concerns in the South, and the nature of the consocial but politically weighted Assembly in the North, which was developed to accommodate the sectarian political divide rather than environmental or other 'social' concerns. In the main, these groups are representative of those without power under the new political dispensations. Non-economic actors such as women's groups, the unemployed, immigrants and environmentalists have been marginalised by the coalition of mainstream parties, trade unions, large farmers' groups and the business lobby in the Republic, and in the North by most of the political parties, whose focus is on controlling the levers of power in the Assembly.

In the Republic of Ireland, there is a tendency within the existing neocorporatist system to focus on the technocratic aspect of policy-making capacity which creates difficulties for political parties who wish to represent the concerns of the professional middle class, due to the tendency of professionals to have concerns that go beyond the economic. This void can be filled by the campaigns of environmental movements, as public sector professionals such as academics and those with alternative forms of expertise mobilise and challenge the structures of closed corporatist power. The critique of closed political 
systems in European states such as Germany and Austria can be applied to Ireland's own system of neo-corporatist closure with the question: 'What is it about neo-corporatist arrangements that have stimulated the development of Green movements in those countries' (Scott 1990, p. 144)? While this question may not be as relevant in the Irish case, the persistence of environmental campaigns and the emergence since 2007 of the Irish Green Party as partners in a coalition government dealing with the incineration issue provides some congruence with European Green movements.

Corporatist and neo-corporatist centralised arrangements and the processes of inclusion or exclusion that result from the state's facilitation or repression of access to political structures creates a 'dimension of political opportunity' (Tarrow 1994, 1998) for movements such as environmental campaigners. 'Inclusive' corporatist arrangements are usually 'restricted to employers and organised labour' (Scott 1990, p. 144). The restricted nature of corporatist arrangements 'means that groups excluded from these processes may mobilise at grassroots level, knowing that 'normal' challenges are closed off' (ibid.). As political opportunities evolved on various levels during this period, external political factors, such as economic growth, wider North-South cooperation, EU legislation and the formation of the EPA all influenced the events surrounding these cases.

The apparent disregard by authorities for communities in both jurisdictions in Ireland can be seen as the primary contributing factor (and political opportunity) for environmental movement responses to policy. These various movements shared certain features, and drew from similar pools of internal and external resources, as an anti-multinational and NIMBY frame in the 1970s and 1980s gave way to concerns about the negative impacts of the economic boom in the 'waste management' frame of the 1990s and 2000. GSE's own campaigns were able to use these internal and external resources, as the shifting dynamic of political opportunities evolved, and 'influential allies' were available. The volatile pattern of political opportunities also provided 'unstable alignments' (Tarrow 1994, pp. 85-89) as the state's own legislative framework on waste issues remained concentrated on profitability rather than sustainability, and provided local successes for regional campaigns. As the Irish state's aim of eight regional incinerators has now been reduced to just three (in Dublin, Meath and Cork), local 'success' has been offset by these revised plans for larger incinerators in urban areas.

The political outcomes for individual campaigners have been equally mixed. In 2006, the Green parties in both jurisdictions were unified. In 2007, the Greens had their first representative elected to the Assembly in Belfast. Prominent southern Green party members had come to the fore in local antiincinerator campaigns. The Greens took the ultimate step towards increasing their access to power after the 2007 general election by entering a coalition government with Fianna Fáil (Leonard 2008a, b). The emergence of the Green party as a coalition partner has had mixed results in relation to incineration, with disagreement about three of the originally proposed eight incinerators 
continuing. Their combination of framing approaches, combined with the utilisation of EU directives as the basis for legal challenges, represented some success for community groups opposed to the state's waste policy. While plans for incinerators in Dublin (Poolbeg), Meath (with planning permission announced in July 2008) and Cork are still part of state policy, campaigners have continued to oppose their introduction. The Irish Greens have been criticised for their participation in a coalition government which has continued attempts to introduce incineration.

Events in Northern Ireland surrounding the Du Pont campaign seem to vindicate the findings from interviews and focus groups that one of the clearest problems there 'is the democratic deficit in terms of the participation in the construction and implementation of policy' (Fagan et al. 2001, p. x). Fagan et al. advocate genuine forms of consultation and participation at all stages of the waste management process that might reduce particularistic local reactions against state policies and practices. This was, in part, a response to views such as those found among local authorities that tended to see the issue of waste management in terms of how to avert local opposition to incineration through financial inducements and by bypassing local councillors. This may be a self-defeating approach given that research has shown that the type of 'environmental empowerment' necessary for good waste management practice occurs when community control over environmental events exists. Northern Ireland's government has also continued to develop plans for an incinerator in the Belfast region, with environmental groups remaining vigilant.

These case studies demonstrate the complexities surrounding the issue of state or corporate plans for dealing with an ongoing waste crisis in the face of local community concerns about the environment. We have demonstrated that from a governance perspective, the dichotomies between centralised forms of power and community-based movements derived from local political alliances indicate the need for local consultation at the planning and implementation level. While this may delay the introduction of critical infrastructure required by existing levels of consumption, the benefits for the wider political process would include an increased sense of confidence in the processes of development in regions that, for whatever reason, may feel marginalised from the central planning process. The responses of community groups in both jurisdictions can also be seen to have impacted on local politics, and provided an outlet for concerns about wider issues such as democratic deficit. The prevalence of community responses indicates the extent to which degrees of populist local governmentality are manifested in Ireland's body politic in both the North and the Republic. Ultimately, this embedded form of community politics creates an initial but significant layer of civil society which provides an outlet for local political concerns about corporate or state activity, empowers local actors, instigates local political careers and augments local flows of knowledge and networking on issues such as health, politics and regional planning, thereby enhancing the political opportunity framework in a manner that goes beyond NIMBY concerns with the development of regional repertories of power. 
While such power is by its very nature transient and fleeting, the temporary leverage it provides creates moments of access for community activists in a manner which is rarely replicated. As such, the significance of local campaigns such as those described here becomes apparent, as local movements can be seen to make an important contribution to the development of community values, meanings and identities.

\section{Notes}

1. Manlio Cinalli (2002) has drawn our attention to some interesting specifics of environmental politics in divided societies.

2. The latter stood at $19 \%$ in early 2009 , and the former at $34 \%$.

\section{References}

Allen, R., 1992. Waste Not Want Not. London: Earthscan.

Bache, I. and Flinders, M., 2005. Multi-level governance. Oxford University Press.

Bevir, M., 2008. The Westminster model, governance and judicial reform. Parliamentary Affairs, 61 (4), 559-577.

Cinalli, M., 2002. Environmental campaigns and socio-political cleavages in divided societies. Environmental Politics, 11 (1), 163-171.

Davies, A., 2007. A wasted opportunity: civil society and waste management in Ireland. Environmental Politics, 16 (1), 52-72.

European Commision, 1989. A community strategy for waste management communication from the Commission to the Council and to Parliament. Brussels: Commission of the European Communities.

Fagan, G.H., 2003. Sociological reflections on governing waste. Irish Journal of Sociology, 12 (1), 67-85.

Fagan, G.H., et al., 2001. 2001 Waste management strategy: border perspective. Maynooth: National Institute for Regional and Spatial Analysis.

Forfás, 2001. Forfás: Ireland National Policy Advisory Body Annual Report 2001. Dublin: Forfás.

Garavan, M., 2007. Resisting the costs of 'development': local environmental activism in Ireland. Environmental Politics, 16 (5), 844-863.

Gaynor, N., 2008. Transforming participation? Unpublished thesis (PhD). Maynooth: NUI Maynooth Library.

Grove-White, R., 1993. Environmentalism: A New Moral Discourse for Technological Society. In: Kay Milton, ed., 1993 Environmentalism: The View from Anthropology. London: Routledge.

Jordan, J. and Gilbert, N., 1999. Think local - act global: Discourses of environment and local protest. In: S. Fairweather, ed., Environmental futures. Basingstoke: Macmillan, 39-53.

Leonard, L., 2005. Politics inflamed: GSE and the Campaign Against Incineration in Ireland. Ecopolitics Series Volume One. Galway: Greenhouse Press with Choice Publishing.

Leonard, L., 2008a. The Irish Greens in the 2007 general election: dealing with the devil or playing for power. Environmental Politics, 17 (1), 126-130.

Leonard, L., 2008b. The Environmental Movement in Ireland. Dordrecht: Springer.

Murray, M., 2006. Multi-level governance and waste management: the politics of municipal incineration'. Economic and Social Review, 37 (3), 447-465.

Offe, C., 1987. Changing boundaries of institutional social movements since the 1960's. In: C.S. Maier, ed. Changing boundaries of the political. Cambridge UP. 
Peace, A., 1997. A time of reckoning: the politics of discourse in rural Ireland. London: Routledge.

Rootes, C., 2007. Acting locally: the character, contexts and significance of local environmental movements. Environmental Politics, 16 (5), 722-741.

Scott, A., 1990. Ideology and the new social movements. London: Unwin Hyman.

Stoker, G., 1998. Governance as Theory: Five Propositions. International Social Science Journal, 50 (1), 17-28.

Szasz, A., 1994. Eco-populism: toxic waste and the movement for environmental justice. London: UCL Press.

Tarrow, S., 1994. Power in movement: social movements, collective action and politics. New York: Cambridge University Press.

Tarrow, S., 1998. Power in movement: social movements and contentious politics. 2 nd ed. Cambridge University Press. 